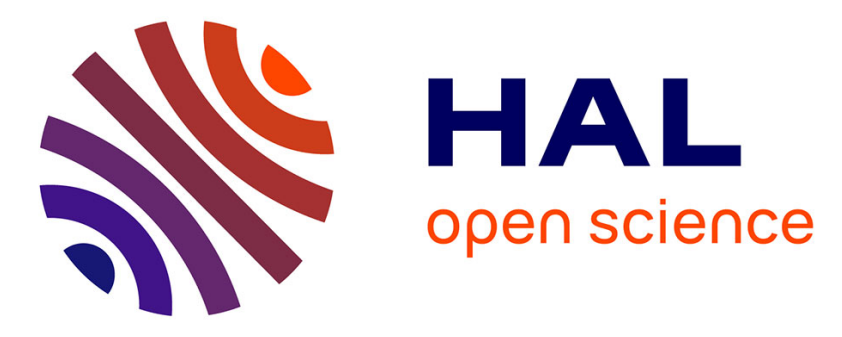

\title{
Modulation of protein release from penta-block copolymer microspheres
}

Minh-Quan Le, Jean-Christophe Gimel, Xavier Garric, Thao-Quyen

Nguyen-Pham, Cédric Paniagua, Jeremie Riou, Marie-Claire Venier-Julienne

\section{- To cite this version:}

Minh-Quan Le, Jean-Christophe Gimel, Xavier Garric, Thao-Quyen Nguyen-Pham, Cédric Paniagua, et al.. Modulation of protein release from penta-block copolymer microspheres. European Journal of Pharmaceutics and Biopharmaceutics, 2020, 152, pp.175-182. 10.1016/j.ejpb.2020.05.009 . hal02612734

\section{HAL Id: hal-02612734 \\ https://univ-angers.hal.science/hal-02612734}

Submitted on 16 Nov 2020

HAL is a multi-disciplinary open access archive for the deposit and dissemination of scientific research documents, whether they are published or not. The documents may come from teaching and research institutions in France or abroad, or from public or private research centers.
L'archive ouverte pluridisciplinaire HAL, est destinée au dépôt et à la diffusion de documents scientifiques de niveau recherche, publiés ou non, émanant des établissements d'enseignement et de recherche français ou étrangers, des laboratoires publics ou privés. 
Research article

\section{MODULATION OF PROTEIN RELEASE FROM PENTA- BLOCK COPOLYMER MICROSPHERES}

Minh-Quan Le ${ }^{1,4}$, Jean-Christophe Gimel ${ }^{1}$, Xavier Garric ${ }^{2}$, Thao-Quyen Nguyen-Pham ${ }^{1}$, Cédric Paniagua $^{2}$, Jérémie Riou ${ }^{1,3}$, Marie-Claire Venier-Julienne ${ }^{1 *}$

${ }^{1}$ Micro et Nanomedecines Translationnelles, MINT, UNIV Angers, UMR INSERM 1066, UMR CNRS 6021, Angers, France

${ }^{2}$ Institut des Biomolécules Max Mousseron (IBMM), UMR 5247, CNRS, Université Montpellier, ENSCM, Montpellier, France

${ }^{3}$ Methodology and Biostatistics Department, Delegation to Clinical Research and Innovation, Angers University Hospital, 49100 Angers, France

${ }^{4}$ Present address : University of Medicine and Pharmacy, Ho Chi Minh City, Vietnam

* Corresponding author:

Micro et Nanomédecines Translationnelles (MINT), INSERM U1066 - CNRS 6021

4 rue Larrey, 49933 Angers Cedex 9, France

E-mail address: marie-claire.venier@univ-angers.fr

Telephone number: +(33) 241226735 


\section{ABSTRACT}

Releasing a protein according to a zero-order profile without protein denaturation during the polymeric microparticle degradation process is very challenging. The aim of the current study was to develop protein-loaded microspheres with new PLGA based pentablock copolymers for a linear sustained protein release. Lysozyme was chosen as model protein and $40 \mu \mathrm{m}$ microspheres were prepared using the solid-in-oil-in-water solvent extraction/evaporation process. Two types of PLGA-P188-PLGA penta-block copolymers were synthetized with two PLGA-segments molecular weight (20 kDa or $40 \mathrm{kDa})$. The resulting microspheres (50P20-MS and 50P40-MS) had the same size, an encapsulation efficiency around $50-60 \%$ but different porosities. Their protein release profiles were complementary: linear but non complete for 50P40-MS, non linear but complete for 50P20-MS. Two strategies, polymer blending and microsphere mixing, were considered to match the release to the desired profile. The (1:1) microsphere mixture was successful. It induced a bi-phasic release with a moderate initial burst (around 15\%) followed by a nearly complete linear release for 8 weeks. This study highlighted the potential of this penta-block polymer where the PEO block mass ratio influence clearly the $\mathrm{Tg}$ and consequently the microsphere structure and the release behavior at $37^{\circ} \mathrm{C}$. The $(1: 1)$ mixture was a starting point but could be finely tuned to control the protein release.

Keywords: protein sustained release, penta-block copolymer, microsphere, microencapsulation, release modulation.

Abbreviations: PLGA, poly(D,L-lactic-co-glycolic acid); PLA, Polylactic acid; MS, microsphere; PEO, poly(ethylene oxyde); PPO, poly(propylene oxyde); S/O/W, solid-inoil-in-water emulsion; DMF, dimethylformamide; DCM, methylene chloride; Tris, trizmabase; P188, Poloxamer 188; THF, tetrahydrofuran; $\mathrm{CHCl}_{3}$, chloroform; DMSO, Dimethyl sulfoxide; NMR, nuclear magnetic resonance; PVA, Poly(vinyl alcohol); SEM, scanning electron microscopy; DSC, differential scanning calorimetry; Tg, glass transition temperature; EE, encapsulation efficiency; BSA, Bovine serum albumin; IQR, interquartile range; PEO, polyethylene oxyde. 
During the past two decades, there has been a great interest in controlled release of drugs particularly for therapeutic proteins. Proteins are usually injected so it is crucial to reduce the frequency of the injections, to increase the confort and patient compliance [1][2][3]. Many approaches have been proposed to carry and deliver protein following continuous and sustained manners. Among those, protein encapsulation in microspheres using biodegradable and biocompatible polymers such as poly(D,L lactide-co-glycolide) (PLGA) [4] were often used to control the release over several weeks.

However protein sustained delivery from PLGA-based microspheres (MS) is still a challenge due to the variety of protein native structures, their instability particularly during the polymer degradation [5], and their very low diffusivity into PLGA matrixes [6]. To limit this drawback, a central hydrophilic segment such as poly(ethylene oxyde) (PEO) was polymerized with PLGA to obtain a polymer triblock [7][8][9][10][11]. The protein release from A-B-A type triblock was enhanced as the presence of hydrophilic segments in multi-block copolymers facilitated the microsphere swelling during the release and provided protein diffusion pathways [7][16]. But an incomplete release was still observed due to the degradation of the entrapped protein into the microsphere core [12]. In addition, it was shown that by adding free poloxamer in the formulation, the protein degradation [Ref to add] and its adsorption on PLGA were reduced [14][15]. In that respect, to modulate both the hydrophilic/hydrophobic balance of the polymer and improve the protein stability, a penta-block was synthetized by copolymerizing PLGA with amphiphilic triblock polymers such as poloxamers [13][17].

In the literature, many efforts have been made to develop different strategies to modulate the protein release profile. Most of them relied on polymer blend strategies [18][19][20][21], whereas the strategy of mixing different types of PLGA-based microspheres was rarely addressed. Nevertheless, releasing a protein according to a zeroorder profile without protein denaturation during the polymer degradation process is still very challenging. 
The aim of the current study was to modulate the protein release from the penta-block copolymer microspheres. Lysozyme was chosen as a model protein [22] and $40 \mu \mathrm{m}$ microspheres were prepared using the solid-in-oil-in-water $(\mathrm{S} / \mathrm{O} / \mathrm{W})$ solvent extraction/evaporation process [13]. Penta-block copolymers were synthetized with two PLGA-segments molecular weight (20 kDa or $40 \mathrm{kDa}$ ). Various strategies (i.e. polymer blending, microsphere mixing) were also considered to modify the release profile while maintaining the completion of the protein release over 8 weeks. The proposal of a strategy to achieve a complete active protein release from microspheres with the desired profile was the main contribution of this study.

\section{MATERIALS AND METHODS}

\subsection{Materials}

Lysozyme (chicken egg white) and its substrate Micrococcus lysodeikticus, glycofurol, dimethylformamide (DMF), methylene chloride (DCM), acetone, and trizmabase (Tris) were purchased from Sigma-Aldrich (Saint-Quentin Fallavier, France). Poloxamer (P188, Pluronic ${ }^{\circledR}$ F68) was obtained from BASF (Levallois-Perret, France). D,L-lactide and glycolide were purchased from Corbion (Gorinchem, The Netherlands). Polyvinyl alcohol (Mowiol ${ }^{\circledR} 4-88$ ) was supplied by Kuraray Specialities Europe (Frankfurt, Germany).

Tin(II) 2-ethylhexanoate $\left(\mathrm{Sn}(\mathrm{Oct})_{2}, 95 \%\right)$, dichloromethane (DCM), diethyl ether, tetrahydrofuran (THF), chloroform $\left(\mathrm{CHCl}_{3}\right)$ were purchased from Sigma-Aldrich (StQuentin Fallavier, France).

The poloxamer 188 (P188) is a commercial tri-block copolymer of PEO and poly(propylene oxyde) (PPO) with general formula $\mathrm{HO}\left(\mathrm{C}_{2} \mathrm{H}_{4} \mathrm{O}\right)_{80}\left(\mathrm{C}_{3} \mathrm{H}_{6} \mathrm{O}\right)_{27}\left(\mathrm{C}_{2} \mathrm{H}_{4} \mathrm{O}\right)_{80} \mathrm{H}$ [23]. Two penta-block copolymers (named 50P20 and 50P40) were synthesized by ringopening polymerization of D,L lactide and glycolide from P188 as initiator. Typically, $5 \mathrm{~g}$ of P188 and various amounts of D,L-lactide and glycolide (respectively 25 and $20.1 \mathrm{~g}$ for 
the 50P40 and 13 and $10.1 \mathrm{~g}$ for the 50P20) were introduced into two flasks, then were vacuum dried for $24 \mathrm{~h}$. Tin (II)-2 ethylhexanoate $(0.1 \%$ of the number of hydroxyl functions of P188) was added in dried polymerization flasks. After degassing, the flask was sealed under vacuum and polymerization was carried out at $130^{\circ} \mathrm{C}$ for 5 days. The copolymers were recovered by dissolution in dichloromethane and precipitated in cold ethanol. The precipitated copolymers were filtered and dried under reduced pressure up to constant weight. The composition of copolymers was investigated by nuclear magnetic resonance spectroscopy (1H-NMR spectroscopy) at room temperature with an AMX300 Bruker $^{\circledR}$ spectrometer $(300 \mathrm{MHz})$, using DMSO as a solvent and trimethylsilane as the internal standard. The dispersity (Đ) was determined by size exclusion chromatography (SEC, Shimadzu $^{\circledR}$, Japan) using two mixed medium columns PLgel $5 \mu$ m MIXED-C (300 $\times 7.8 \mathrm{~mm})$, a Shimadzu ${ }^{\circledR}$ RI detector 20-A and a Shimadzu ${ }^{\circledR}$ UV detector SPD-20A (270 nm) $\left(40^{\circ} \mathrm{C}\right.$ thermostatic analysis cells). Tetrahydrofuran (THF) was the mobile phase with $1 \mathrm{~mL} / \mathrm{mn}$ flow at $30^{\circ} \mathrm{C}$ (column temperature).

The general formula of the resulting penta-block copolymer is (PLGA-PEO-PPO-PEOPLGA). The PLGA segments contained 25\% D-lactic units, 25\% L-lactic units and 50\% glycolic units. The penta-block copolymer 50P40 was composed of one central segment of P188 (Mn=8,400 g/mol) and two segments of PLGA $(\mathrm{Mn}=40,000 \mathrm{~g} / \mathrm{mol}$ each $)$ at the ends, the copolymer average molecular mass $(\mathrm{Mn})$ was $88,400 \mathrm{~g} / \mathrm{mol}(\underline{Đ=1.72})$. The penta-block copolymer 50P20 was composed of one central segment of P188 ( Mn=8,400 g/mol) and two segments of PLGA ( $\mathrm{Mn}=20,000 \mathrm{~g} / \mathrm{mol}$ each) at the ends, the copolymer average molecular mass was (Mn) 48,400 g/mol ( $\underline{Đ=1.51})$.

\subsection{Microsphere preparation}

\subsubsection{Preparation of 50P40-MS or 50P20-MS}

Copolymer microspheres (50P40-MS and 50P20-MS) were prepared as described previously (called thereafter the standard procedure) [12]. The theoretical protein loading was $0.6 \%(w / w)$. Briefly, lysozyme and P188 (ratio lysozyme/P188 1/10 (w/w)) were 
dissolved in water. Then $3.12 \mathrm{~g}$ of glycofurol were introduced in the solution to form a suspension. After an incubation at $4^{\circ} \mathrm{C}$ for $30 \mathrm{~min}$, the nanoprecipitated protein was recovered by centrifugation $\left(10,000 \mathrm{~g}, 4^{\circ} \mathrm{C}, 30 \mathrm{~min}\right)$. The precipitated protein was dispersed in $2 \mathrm{~mL}$ solution of dichloromethane/acetone $3 / 1(\mathrm{v} / \mathrm{v})$ containing $150 \mathrm{mg}$ of penta-block copolymer. The suspension was emulsified in $90 \mathrm{~mL}$ PVA $(6 \% \mathrm{w} / \mathrm{v})$ at $1{ }^{\circ} \mathrm{C}$ and mechanically stirred at $1,000 \mathrm{rpm}$ for $1 \mathrm{~min}$ in a glass vessel $(4.5 \mathrm{~cm}$ inside diameter) with a dual wall to control the temperature. $100 \mathrm{~mL}$ of cold deionized water were then added and the emulsion was stirred for 10 min more. Then, the emulsion was poured into a second glass vessel $(10 \mathrm{~cm}$ inside diameter, with a dual wall) containing $500 \mathrm{~mL}$ of deionized water $\left(1^{\circ} \mathrm{C}\right)$ and stirred continuously at $550 \mathrm{rpm}$ during $20 \mathrm{~min}$ to extract the $\underline{\text { solvent. In all steps, an overhead stirrer with a } 4 \text { blades propeller was used (Heidolph }{ }^{\circledR}}$ RZR 2041, Schwabach, Germany). Finally, microspheres were recovered by filtration on a $5 \mu \mathrm{m}$ filter (HVLP type, Millipore SA, Guyancourt, France), washed, freeze-dried and stored at $-20^{\circ} \mathrm{C}$.

\subsubsection{Preparation of microspheres using polymer blend}

The formulation process was similar to the standard procedure describe above. The mixture of lysozyme and P188 was nanoprecipitated in glycofurol using the same protocol. In this case, a physical blend of 50P40 and 50P20 copolymers (with a weight ratio 1/1) was dissolved in DCM/acetone (3/1, v/v). The nanoprecipitated protein was dispersed in a $2 \mathrm{~mL}$ solvent mixture containing $150 \mathrm{mg}$ of the copolymer blend. Later on, the emulsification and solvent extraction/evaporation steps were performed using the standard procedure described above.

\subsubsection{Strategy of batch mixing following the preparation of microspheres}

The 50P40-MS and 50P20-MS were prepared separately following the standard procedure. Then, equal amounts of 50P40-MS and 50P20-MS (15 mg) were suspended in $1 \mathrm{~mL}$ of water. The mixture was gently mixed using the vortex prior to be freeze-dried. The resulting microsphere mixture $(50 \mathrm{P} 40-\mathrm{MS} / 50 \mathrm{P} 20-\mathrm{MS} 1 / 1, \mathrm{w} / \mathrm{w})$ was stored at $-20^{\circ} \mathrm{C}$ for further study. 


\subsection{Microsphere characterization}

\subsubsection{Microsphere morphology and mean size}

The microsphere mean size was measured using a Coulter ${ }^{\circledR}$ Multisizer (Coultronics, Margency, France). Microspheres were dispersed in an isotonic saline solution prior to be analyzed (Isoton ${ }^{\circledR}$ II solution, Coultronics, Margency, France).

Microsphere surface morphology was observed using scanning electron microscopy SEM (JSM 6310F, JEOL, Paris, France). Freeze-dried microspheres were mounted onto metal stubs using double-sided adhesive tape, vacuum-coated with a film of carbon using a MED 020 (Bal-Tec, Balzers, Lichtenstein) before being analyzed. The microsphere internal morphology was studied using the following process [13]. An appropriate amount of microspheres was dispersed into $1 \mathrm{~mL}$ of Tissue-Tek ${ }^{\circledR}$ (Sakura Finetek, USA) and freezed $\left(-20^{\circ} \mathrm{C}, 1\right.$ hour $)$. Resulting blocks were cut into slices $(20 \mu \mathrm{m}$-thickness $)$ at $-15^{\circ} \mathrm{C}$ using a micro-cutting device (Leica, Nanterre, France). Slices were rinsed three times with cold water $\left(1^{\circ} \mathrm{C}\right)$ before being freeze-dried. Samples were then analyzed by SEM as described above.

\subsubsection{Glass transition temperature of the copolymers}

To measure the glass transition of raw copolymers and microspheres, differential scanning calorimetry (DSC) analysis was carried out. DSC measurements were performed under nitrogen on a Perkin-Elmer Instrument DSC 6000 thermal analyzer. Samples were subject to a first heating ramp from $-50^{\circ} \mathrm{C}$ to $200^{\circ} \mathrm{C}\left(10^{\circ} \mathrm{C} / \mathrm{min}\right)$, followed by a cooling step $\left(\underline{\left.10^{\circ} \mathrm{C} / \mathrm{min}\right)}\right)$ and finally a second heating ramp from $-50^{\circ} \mathrm{C}$ to $200^{\circ} \mathrm{C}\left(\underline{\left.10^{\circ} \mathrm{C} / \mathrm{min}\right)}\right.$ was performed to measure the glass transition temperature $(\mathrm{Tg})$.

\subsubsection{Protein encapsulation efficiency}

The amount of entrapped lysozyme was determined by dissolving $5 \mathrm{mg}$ of microspheres in $0.9 \mathrm{~mL} \mathrm{DMF}$ in a silanized glass tube at room temperature under agitation (1 hour). Then, $3 \mathrm{~mL}$ of a Tris solution (Tris $0.05 \mathrm{M}$ buffer and $0.09 \% \mathrm{w} / \mathrm{v} \mathrm{NaCl}, \mathrm{pH} 7.4$ ) was added and the agitation was carried on for 1 hour more. The resulting solution was introduced into a 
Micrococcus lysodeikticus test for active lysozyme quantification as described previously [13]. The protein encapsulation efficiency (EE) was determined in triplicate.

\subsubsection{In vitro release of active lysozyme from microspheres}

$5 \mathrm{mg}$ of lysozyme-loaded microspheres were dispersed in $375 \mu \mathrm{L}$ of buffer solution (Tris $0.05 \mathrm{M}$ buffer, $\mathrm{pH} 7.4$, containing $0.1 \% \mathrm{w} / \mathrm{v} \mathrm{BSA}$ and $0.09 \% \mathrm{w} / \mathrm{v} \mathrm{NaCl}$ ) [24] using $1.5 \mathrm{~mL}$ polyethylene microtubes (Eppendorf type). The suspension was incubated in a water bath $\underline{\text { at } 37^{\circ} \mathrm{C} \text { and oscillated on a rack at } 125 \mathrm{rpm}}$. At defined time intervals, tubes were removed and centrifuged for $5 \mathrm{~min}$ at 3,000 $\mathrm{g}$. The supernatant was collected, tested for active lysozyme quantification and replaced by fresh buffer. Release profiles were determined on at least 3 different microsphere batches and for each one, at least 3 experiments were carried out.

To investigate the effect of the release temperature on the microsphere morphology, release tests were carried out in a similar way but the water bath was controlled at $22^{\circ} \mathrm{C}$ or placed in a $4^{\circ} \mathrm{C}$ cold chamber.

\subsubsection{Microsphere morphology change during the release test}

$15 \mathrm{mg}$ of lysozyme-loaded microspheres were dispersed into $1,050 \mu \mathrm{L}$ of buffer solution (Tris $0.05 \mathrm{M}$ buffer, $\mathrm{pH} 7.4$, containing $0.1 \% \mathrm{w} / \mathrm{v} \mathrm{BSA}$ and $0.09 \% \mathrm{w} / \mathrm{v} \mathrm{NaCl}$ ) in $1.5 \mathrm{~mL}$ polyethylene microtubes (Eppendorf type). The suspension was incubated in a water bath at $37^{\circ} \mathrm{C}$ and oscillated on a rack at $125 \mathrm{rpm}$. After a defined duration, tubes were centrifuged for $5 \mathrm{~min}$ at 3,000 $\mathrm{g}$. The supernatant was removed and the remaining particles were washed 3 times with cold water $\left(1^{\circ} \mathrm{C}\right)$ before being freeze-dried. For microsphere cross-sectional observations, microspheres were cut and analysed with SEM as described above.

\subsection{Statistical Analysis}

The quantitative variables were described using the mean $+/-95 \%$ confident interval when variable distribution was normal, and otherwise using median and Inter-Quartile Range. 
Both batches and samples were taken into account to assess the global variability of the process. In view of the observation, a non-parametric Mann-Whitney test was performed when necessary.

\section{RESULTS AND DISCUSSION}

\section{$\underline{\text { 3.1 Glass transition temperature }}$}

The glass transition temperature ( $\mathrm{Tg}$ ) of raw copolymers (table 1 ) was $24.3^{\circ} \mathrm{C}$ for $50 \mathrm{P} 40$ and $9.6^{\circ} \mathrm{C}$ for $50 \mathrm{P} 20$. Both values were smaller than the ones reported in the literature for bulk PLGA where $\mathrm{Tg}$ varies from around $50^{\circ} \mathrm{C}$ for $40 \mathrm{kDa}$ to around $40^{\circ} \mathrm{C}$ for $20 \mathrm{kDa}$ PLGA [25]. In a previous study, it was shown that when PLGA blocks were copolymerized with a central PEO blocks, the resulting triblock Tg decreased noticeably as the relative amount of the hydrophilic block was increased [12]. This was also observed in the present study where the relative amount of PEO increased from 9.5\% (w/w) in 50P40 to $17 \%(\mathrm{w} / \mathrm{w})$ in 50P20. Decreases of Tg were mainly due to plasticizing effects provided by the PEO block [26].

Besides, Tg values of uncharged lyophilized microspheres were very closed to those of raw copolymers. It is known from the literature that the surfactant, especially PVA due to its hydroxyl groups [27], and residual solvents like DCM [28] can significantly impact Tg values. Then, it can be assumed a good elimination of PVA and residual solvents during $\underline{\text { the process. }}$

On the other hand, the co-encapsulated poloxamer lowered the $\mathrm{Tg}$ values of microspheres, the effect being more pronounced for 50P20-MS where $\mathrm{Tg}$ fell from $9.1^{\circ} \mathrm{C}$ to $5.5^{\circ} \mathrm{C}$. Incorporating the lysozyme enhanced these phenomena. Plasticizing effects of additives like pegylated compounds or proteins have been widely reported in the literature [29][30].

These observations were important to explain the morphology of microspheres formulated at $1{ }^{\circ} \mathrm{C}$ and their behaviors during the protein release process at $37^{\circ} \mathrm{C}$. In this work, $\mathrm{Tg}$ 
were measured on dry (lyophilized) products. But it is known that hydrated products, especially porous ones, display lower $\mathrm{Tg}[31]$. Any how it was reasonable to assume that hydration should not modify our conclusions as the Tg of hydrated 50P20-MS should still be lower than the one of hydrated 50P40-MS.

[Table 1] Glass transition temperatures of different copolymers.

\section{$\underline{\text { 3.2. Morphology, mean size and encapsulation efficiency }}$}

Both types of microspheres were formulated below the glass transition temperature of their constitutive copolymer. For 50P40, the microsphere formation took place at 5\% below Tg. They exhibited smooth surface with no visible pores. Their internal structure was porous with closed small pores distributed uniformly in the volume (Figure 1A). For 50P20, the microsphere formation took place at $1 \%$ below $\mathrm{Tg}$. They were highly porous with numerous interconnected pores visible on the surface as well as in the interior (Figure 1B).

During the solvent/cosolvent extraction step, the phase separation occurs into the initial polymer solution droplets with coexisting polymer rich and polymer poor phases. The further removal of solvent induces the glass transition in the polymer rich phase, and the microsphere solidification comes to an end. The phase transition kinetics becomes arrested as the glassy state is reached in the dense polymer phase while the polymer poor phase will form the future pores in the microsphere structure. The competition between the ongoing phase separation and the appearance of the glassy state has been described and modeled in the literature [32][33] and could explain the structural differences observed. 50P40-MS reached the glassy state faster than 50P20-MS and consequently developed less porous structures compared to 50P20-MS.

The median particle size and the interquartile range [IQR] of 50P40-MS were respectively $39.0 \mu \mathrm{m}[38.7,41.2]$ and $38.3 \mu \mathrm{m}$ [37.6, 41.5] for 50P20-MS (Figure 1C). Encapsulation efficiency (EE) values ranged from 52 to $61 \%$ regardless the copolymers used (Figure 1C). Both types of microspheres were not significantly different considering their size ( $p=$ 
$0.4681)$ and their encapsulation efficiency $(\mathrm{p}=0.6501)$. This result may be due to a statistical lack of power (the sampling was too small) or to the absence of real differences in the size or EE of 50P20-MS and 50P40-MS.

The rather low encapsulation yield can be attributed to the leakage of the protein into the external aqueous phase during the microparticle formation [34][35].

[Figure 1] Characterisation of MS produced using copolymers: (A) external/internal structure of 50P40-MS; (B) external/internal structure of 50P20-MS. In both cases, white scale bars represents $10 \mu \mathrm{m}$; (C) particle mean size $(n=5)$ and encapsulation efficiency ( $n=5$ for $50 \mathrm{P} 40-\mathrm{MS}$ and $n=10$ for 50P20-MS) as function of copolymers. Grey plot aims to compare the distribution of both interest variable as function of copolymers types. The boxes indicate the $75^{\text {th }}$ percentile (upper horizontal line), median (black bold horizontal line), and the $25^{\text {th }}$ (lower horizontal line) percentiles of the distribution. Surrounding the boxed (shaded area) on each side is a rotated kernel density plot.

\subsection{Protein release profiles}

Drug release from PLGA-based microspheres can follow mono-, bi- or tri-phasic profiles depending on various factors including the hydrophilic balance or their morphology [29]. Polymer characteristics (Tg), porosity and mean particle size are recognized as critical factors for the protein release profile from PLGA-based microspheres [37][38]. In the present study, the microsphere diameter was kept constant to avoid its impact on the profile. The active protein release from 50P40-MS (dense surface/porous interior; Figure 1A) was carried out during 8 weeks and compare to 50P20-MS (porous surface/porous interior; Figure 1B).

[Figure 2] Average protein release profiles from microspheres of copolymer 50P20 (triangles) and copolymer 50P40 (squares). Error bars represent 95\% confident intervals of mean values ( $n=24$ for $50 \mathrm{P} 20$ and $n=10$ for $50 \mathrm{P} 40$ ). The dashed line is a guide to the eyes, it figures out the ideal desired profile. 
Figure 2 shows release profiles for both 50P40-MS and 50P20-MS. Lysozyme release from 50P40-MS complied with a bi-phasic profile with a moderate burst $(11.2 \% \pm 1.3 \%$ released after 24 hours). The release was then sustained and linear until Day 56 but the cumulated amount was $53.8 \% \pm 6.2 \%$ only. Despite a highly porous surface and a porous internal structure, 50P20-MS exhibited a biphasic protein release with also a moderate burst after 24 hours $(15.2 \% \pm 1.1 \%)$, followed by a sustained and complete release (ending-up with $93.4 \% \pm 3.1 \%$ of active lysozyme released) but not linear as emphasized by the dashed line in figure 2 .

For protein loaded microspheres, a bi-phasic release profile is commonly achieved with porous microspheres [38][39] or with microspheres having non-porous surface but porous internal structure [40]. The mechanism of drug release from PLGA is impacted by both the diffusion process and the polymer erosion [41][42]. However, due to the very low diffusion coefficient of a protein embedded in a PLGA matrix, its transport through the pores was proposed as the main release mechanism [6].

\subsection{Microsphere size and morphology change during the release test}

To clarify involved mechanisms, particle sizes and morphologies were monitored during the release (Figure 3 and Figure 4). After 2 days, 50P40-MS showed the appearance of few pores on their surface with an increase of the pore density in the peripheral structure (Figure 4-A2). These morphology changes were along with a $12 \%$ size increase (Figure 3 ). This phenomena was more marked on Day 10 with a stabilised size until Day 28 (Figure 4-A3).

[Figure 3] Evolution of microsphere mean sizes as a function of the release time for 50P20 (triangles) and 50P40 (squares). Error bars represent 95\% confident intervals of the mean value ( $n=6$ for $50 \mathrm{P} 20$ and $50 \mathrm{P} 40$ ).

A delayed polymer degradation and erosion were previously observed for porous PLGAbased microspheres and have been explained by facilitated interchanges between the 
internal environment and the external buffer medium. This reduced the acidification and autocatalysis phenomena [43][44] prolonging the drug release duration [45].

[Figure 4] Morphological changes of 50P40-MS (left column) and 50P20-MS (right column) during the release test (white scale bars represent $10 \mu \mathrm{m}$ ). After Day $28 \mathrm{MS}$ could not be observed by SEM.

The active protein release was incomplete and a plateau around 54\% was observed from Day 56 up to Day 70 (data not shown, $n=3$ ). This phenomenon has already been observed for $60 \mu \mathrm{m}$ PLGA-PEG-PLGA microspheres and it was demonstrated that the protein was entrapped and degradated within the dense microsphere core [12].

The scenario was totally different for 50P20-MS which contained a higher amount of hydrophilic segments than 50P40-MS (17\% vs $9.5 \% \mathrm{w} / \mathrm{w}$ respectively) with a lower $\mathrm{Tg}$ $\left(3.5^{\circ} \mathrm{C}\right.$ vs $15.9^{\circ} \mathrm{C}$ respectively, see Table 1$)$.

The 50P20-MS size decreased continuously from the beginning to Day 28 (Figure 3). It appeared clearly from the SEM images that a pore-closing process occurred during the first 2 days. It was accompanied by a complete reorganization of the internal structure. Microsphere structure became homogeneous with no visible pores neither on the surface nor in the interior. This phenomenon could explain the reduced burst while a significant one is classically expected for microsphere showing an initial porous surface [46][47].

From Day 10, microspheres were no longer spherical and became brittle due to the polymer degradation/erosion.

To explain the drastic change observed at Day 2 for 50P20-MS, their morphology was investigated for various temperature of the release media, $3^{\circ} \mathrm{C}, 22^{\circ} \mathrm{C}, 37^{\circ} \mathrm{C}$ (Figure 5). These temperatures corresponded to three different relative distances to the dry microsphere $\operatorname{Tg}(-0.2 \%,+6.7 \%,+12,1 \%$ respectively). From figure 5 , it was clearly evidenced that no reorganisation occurred at $3{ }^{\circ} \mathrm{C}$. A moderate one can be seen at $22^{\circ} \mathrm{C}$ and a complete one with, a pore closing process, was observed at $37^{\circ} \mathrm{C}$. This demonstrated that the mobility of the polymer chains was a key parameter to explain this reorganization. 
[Figure 5] Internal structure at day 2 of 50P20-MS incubated into the release medium at different temperature : (A): $3^{\circ} \mathrm{C} ;(\mathrm{B}): 22^{\circ} \mathrm{C} ;(\mathrm{C}): 37^{\circ} \mathrm{C}$. White scale bars represent $10 \mu \mathrm{m}$.

50P20-MS have shown a nearly complete active protein release after 8 weeks $(93 \pm 3 \%)$ with a moderate burst but a non constant release rate (See the ideal expected profile in figure 2), while 50P40-MS had a constante rate after a moderate burst, but did not achieve a complete release $(54 \pm 7 \%)$.

Both kinds of delivery system were good candidates for further optimizations using combination strategies. Indeed, a complete protein release with a moderate burst and a constant rate could ideally be wanted for some given therapeutic applications.

\subsection{Adjustment of protein release profile}

We have tried to design an optimal protein delivery system using two strategies: either a polymer blending or a microsphere mixing.

\subsubsection{Release profile from polymer blending microspheres}

The mean size $(39.9 \pm 3.4 \mu \mathrm{m})$ and encapsulation yield $(45.9 \pm 1.9 \%) \quad(n=3)$ of microsphere from polymer blending (hereafter called blend-microspheres) were rather similar to those of 50P40-MS and 50P20-MS. Blend-microspheres exhibited numerous pores on the surface and in the internal structure (Figure 6-A1). Regarding the release of the protein (Figure 6-A2), the initial burst $(20.4 \pm 1.0 \%)$ was higher than previously observed. Then the subsequent protein release was rather linear from Day 1 to Day 42 $\left(\mathrm{R}^{2}=0.9026\right)$ and reached a plateau $(69.1 \pm 4.9 \%$ on Day 56$)$. This kind of strategy has already been used with more or less success for PLA and PLGA microspheres [18][21].

In the present study, the polymer blend strategy was not an improvement.

[Figure 6] (A1) Initial morphology of blend-MS (white scale bars represent $10 \mu \mathrm{m}$ ); (A2) average protein release profile from microspheres of a copolymer blend 50P20 and 50P40 (see text for details). Error bars represent 95\% confident intervals of mean values $(n=13)$; (B1) Initial morphology of mix-MS, porous particles represent 50P20-MS while non- 
porous surface particles correspond to 50P40-MS (white scale bar represents $10 \mu \mathrm{m})$; (B2) Average protein release profile from a mixture of microspheres of copolymer 50P20 and 50P40 (see text for details). Error bars represent 95\% confident intervals of mean values $(n=8)$. The red straight line represents a linear fit to the data $\left(\mathrm{R}^{2}=0.9795\right)$ from Day 1 to Day 56.

\subsubsection{Release profile from a mixture of microspheres}

Concerning the microsphere mixing strategy, SEM picture (Figure 6 - B1) clearly revealed the two different types of microspheres (hereafter called Mix-microspheres). The initial burst was not significantly modified $(15.2 \pm 4.0 \%)$. Then the subsequent protein release was linear from Day 1 to Day $49\left(\mathrm{R}^{2}=0.9915\right)$ and reached a plateau $(82.3 \pm 2.6 \%$ on Day 56) (Figure 6 - B2). This was an improvement in the protein release control compared to the non linear profile of 50P20-MS.

Hickey and co-workers [48] developed PLGA-MS for continuous delivery of dexamethasone over a month. Authors proposed to use a physical mixture of fresh and predegraded PLGA-MS. The resultant mixture exhibited an interesting profile with a moderated initial burst (from $15 \%$ to $20 \%$ ) followed by a linear release but end up at around 60\% after Day 3. Duvvuri and co-workers [49] prepared a physical mixture of two types of microspheres (containing ganciclovir) and dispersed the mixture into a thermogelling polymer. The resultant mixture exhibited an intermediate release profile compared to individual ones. In spite of a nearly $100 \%$ ganciclovir released after 25 days, the profile was tri-phasic with an initial massive burst. Herein, we successfully prepared a mixture of protein-loaded microspheres with the desired release profile: bi-phasic with a moderate burst, followed by a nearly complete linear release. The current achievement could be considered as a promising protein sustained release system.

\section{CONCLUSION}

The protein release profile from penta-block copolymer microspheres was successfully modulated using a mixture strategy based on 50P20-MS and 50P40-MS. Both had the 
411 same size, a moderate burst and complementary profiles (linear but non complete for 412 50P40-MS; non linear but complete for 50P20-MS) The microsphere mixture (1/1, w/w) 413 induced a bi-phasic protein release profile with a moderate initial release followed by a 414 nearly complete linear protein release over 8 weeks. This study highlighted the potential of 415 this kind of penta-block polymers where the mass ratio of PEO blocks influenced clearly 416 the $\mathrm{Tg}$ and consequently the release behavior at $37^{\circ} \mathrm{C}$ associated with the microsphere 417 mixture strategy. The 1:1 mass ratio was used as a starting point but could be finely tune 418 to control the protein release.

\section{Acknowledgements}

421 Polymer synthesis and characterizations (NMR and DSC) were performed using Synbio3 422 platform supported by GIS IBISA and ITMO Cancer (Montpellier, France). The authors 423 would also like to thank the "Service Commun d'Imagerie et de Microscopie d'Angers" 424 for SEM analysis.

\section{Declaration of Interest}

427 The authors declare no conflict of interest. 
[1] A. Patel, M. Patel, X. Yang, A. Mitra, Recent Advances in Protein and Peptide Drug Delivery: A Special Emphasis on Polymeric Nanoparticles, Protein Pept. Lett. 21 (2014) 1102-1120. https://doi.org/10.2174/0929866521666140807114240.

[2] R. Ghasemi, M. Abdollahi, E. Emamgholi Zadeh, K. Khodabakhshi, A. Badeli, H. Bagheri, S. Hosseinkhani, MPEG-PLA and PLA-PEG-PLA nanoparticles as new carriers for delivery of recombinant human Growth Hormone (rhGH), Sci. Rep. 8 (2018) 1-13. https://doi.org/10.1038/s41598-018-28092-8.

[3] S.P. Dipak, M.P. Kosloski, S. V. Balu-Iyer, Delivery of Therapeutic Proteins, J Pharm Sci. 99 (2010) 2557-2575. https://doi.org/10.1002/jps.22054.DELIVERY.

[4] R.F. Pagels, R.K. Prud'homme, Polymeric nanoparticles and microparticles for the delivery of peptides, biologics, and soluble therapeutics, J. Control. Release. 219 (2015) 519-535. https://doi.org/10.1016/J.JCONREL.2015.09.001.

[5] S. Mohammadi-Samani, B. Taghipour, PLGA micro and nanoparticles in delivery of peptides and proteins; problems and approaches., Pharm. Dev. Technol. 20 (2015) 385393. https://doi.org/10.3109/10837450.2014.882940.

[6] S. Fredenberg, M. Reslow, A. Axelsson, Measurement of protein diffusion through poly(D,L-lactide-Co-glycolide)., Pharm. Dev. Technol. $10 \quad$ (2005) 299-307. https://doi.org/10.1081/pdt-54473.

[7] T. Kissel, Y. Li, F. Unger, ABA-triblock copolymers from biodegradable polyester Ablocks and hydrophilic poly(ethylene oxide) B-blocks as a candidate for in situ forming hydrogel delivery systems for proteins., Adv. Drug Deliv. Rev. 54 (2002) 99-134. https://doi.org/10.1016/s0169-409x(01)00244-7.

[8] K. Zhang, X. Tang, J. Zhang, W. Lu, X. Lin, Y. Zhang, B. Tian, H. Yang, H. He, PEGPLGA copolymers: their structure and structure-influenced drug delivery applications., J. Control. Release. 183 (2014) 77-86. https://doi.org/10.1016/j.jconrel.2014.03.026.

[9] S. Feng, L. Nie, P. Zou, J. Suo, Effects of drug and polymer molecular weight on drug release from PLGA-mPEG microspheres, J. Appl. Polym. Sci. 132 (2015) 1-8. https://doi.org/10.1002/app.41431.

[10] Y. Wei, Y. Wang, H. Zhang, W. Zhou, G. Ma, A novel strategy for the preparation of porous microspheres and its application in peptide drug loading., J. Colloid Interface Sci. 478 (2016) 46-53. https://doi.org/10.1016/j.jcis.2016.05.045.

[11] B. Patel, V. Gupta, F. Ahsan, PEG-PLGA based large porous particles for pulmonary delivery of a highly soluble drug, low molecular weight heparin., J. Control. Release. 162 (2012) 310-320. https://doi.org/10.1016/j.jconrel.2012.07.003.

[12] V.-T. Tran, J.-P. Karam, X. Garric, J. Coudane, J.-P. Benoît, C.N. Montero-Menei, M.-C. Venier-Julienne, Protein-loaded PLGA-PEG-PLGA microspheres: A tool for cell therapy, Eur. J. Pharm. Sci. 45 (2012) 128-137. https://doi.org/10.1016/J.EJPS.2011.10.030.

[13] M.-Q. Le, F. Violet, C. Paniagua, X. Garric, M.-C. Venier-Julienne, Penta-block copolymer microspheres: Impact of polymer characteristics and process parameters on protein release, 
[14] A. Giteau, M.-C. Venier-Julienne, S. Marchal, J.-L. Courthaudon, M. Sergent, C. MonteroMenei, J.-M. Verdier, J.-P. Benoit, Reversible protein precipitation to ensure stability during encapsulation within PLGA microspheres., Eur. J. Pharm. Biopharm. 70 (2008) 127-136. https://doi.org/10.1016/j.ejpb.2008.03.006.

[15] A. Paillard-Giteau, V.T. Tran, O. Thomas, X. Garric, J. Coudane, S. Marchal, I. Chourpa, J.P. Benoît, C.N. Montero-Menei, M.C. Venier-Julienne, Effect of various additives and polymers on lysozyme release from PLGA microspheres prepared by an s/o/w emulsion technique, Eur. J. Pharm. Biopharm. 75 (2010) 128-136. https://doi.org/10.1016/J.EJPB.2010.03.005.

[16] J. Buske, C. Konig, S. Bassarab, A. Lamprecht, S. Muhlau, K.G. Wagner, Influence of PEG in PEG-PLGA microspheres on particle properties and protein release., Eur. J. Pharm. Biopharm. 81 (2012) 57-63. https://doi.org/10.1016/j.ejpb.2012.01.009.

[17] M. Morille, T. Van-Thanh, X. Garric, J. Cayon, J. Coudane, D. Noel, M.C. VenierJulienne, C.N. Montero-Menei, New PLGA-P188-PLGA matrix enhances TGF-beta3 release from pharmacologically active microcarriers and promotes chondrogenesis of mesenchymal stem cells, J. Control. Release. 170 (2013) 99-110. https://doi.org/10.1016/j.jconrel.2013.04.017.

[18] R.T. Liggins, H.M. Burt, Paclitaxel-loaded poly(L-lactic acid) microspheres 3: blending low and high molecular weight polymers to control morphology and drug release., Int. J. Pharm. 282 (2004) 61-71. https://doi.org/10.1016/j.ijpharm.2004.05.026.

[19] M.V. Balashanmugam, S. Nagarethinam, H. Jagani, V.R. Josyula, A. Alrohaimi, N. Udupa, Preparation and characterization of novel PBAE/PLGA polymer blend microparticles for DNA vaccine delivery., ScientificWorldJournal. $2014 \quad$ (2014) 385135. https://doi.org/10.1155/2014/385135.

[20] J. Liu, S. Li, G. Li, X. Li, C. Yu, Z. Fu, X. Li, L. Teng, Y. Li, F. Sun, Highly bioactive, bevacizumab-loaded, sustained-release PLGA/PCADK microspheres for intravitreal therapy in ocular diseases, Int. J. Pharm. 563 (2019) 228-236. https://doi.org/10.1016/j.ijpharm.2019.04.012.

[21] B. Gu, D.J. Burgess, Prediction of dexamethasone release from PLGA microspheres prepared with polymer blends using a design of experiment approach., Int. J. Pharm. 495 (2015) 393-403. https://doi.org/10.1016/j.ijpharm.2015.08.089.

501

502

503

504

505

506

507

508

509

510

[22] C.F. Van Der Walle, O. Olejnik, An overview of the field of peptide and protein delivery, Elsevier, 2011. https://doi.org/10.1016/B978-0-12-384935-9.10001-X.

[23] Q.M.. Rowe C.R., Sheskey J.P., Handbook of Pharmaceutical Excipients, 6th ed., Pharmaceutical Press, 2009.

[24] A. Aubert-Pouëssel, D.C. Bibby, M.C. Venier-Julienne, F. Hindré, J.P. Benoît, A novel in vitro delivery system for assessing the biological integrity of protein upon release from PLGA microspheres, Pharm. Res. 19 (2002) 1046-1051. https://doi.org/10.1023/A:1016482809810.

[25] M.O. Omelczuk, J.W. McGinity, The Influence of Polymer Glass Transition Temperature and Molecular Weight on Drug Release from Tablets Containing Poly(DL-lactic Acid), 
Pharm. Res. An Off. J. Am. Assoc. Pharm. Sci. 9 (1992) 26-32. https://doi.org/10.1023/A:1018967424392.

[26] A. Santovena, C. Alvarez-Lorenzo, A. Concheiro, M. Llabres, J.B. Farina, Structural properties of biodegradable polyesters and rheological behaviour of their dispersions and films., J. Biomater. Sci. Polym. Ed. 16 (2005) 629-641. https://doi.org/10.1163/1568562053783768.

[27] J.J. Rouse, F. Mohamed, C.F. van der Walle, Physical ageing and thermal analysis of PLGA microspheres encapsulating protein or DNA., Int. J. Pharm. 339 (2007) 112-120. https://doi.org/10.1016/j.ijpharm.2007.02.026.

[28] K. Vay, W. Frieß, S. Scheler, A detailed view of microparticle formation by in-process monitoring of the glass transition temperature, Eur. J. Pharm. Biopharm. 81 (2012) 399408. https://doi.org/10.1016/j.ejpb.2012.02.019.

[29] S. Fredenberg, M. Wahlgren, M. Reslow, A. Axelsson, The mechanisms of drug release in poly(lactic-co-glycolic acid)-based drug delivery systems--a review., Int. J. Pharm. 415 (2011) 34-52. https://doi.org/10.1016/j.ijpharm.2011.05.049.

[30] X. Wang, S.S. Venkatraman, F.Y.C. Boey, J.S.C. Loo, L.P. Tan, Controlled release of sirolimus from a multilayered PLGA stent matrix, Biomaterials. 27 (2006) 5588-5595. https://doi.org/10.1016/j.biomaterials.2006.07.016.

[31] N. Passerini, D.Q. Craig, An investigation into the effects of residual water on the glass transition temperature of polylactide microspheres using modulated temperature DSC., J. Control. Release. 73 (2001) 111-115. https://doi.org/10.1016/s0168-3659(01)00245-0.

[32] W.-I. Li, K.W. Anderson, P.P. Deluca, Kinetic and thermodynamic modeling of the formation of polymeric microspheres using solvent extraction/evaporation method, $\mathrm{J}$. Control. Release. 37 (1995) 187-198. https://doi.org/10.1016/0168-3659(95)00077-1.

[33] W.-I. Li, K.W. Anderson, R.C. Mehta, P.P. Deluca, Prediction of solvent removal profile and effect on properties for peptide-loaded PLGA microspheres prepared by solvent extraction/ evaporation method, J. Control. Release. 37 (1995) 199-214. https://doi.org/10.1016/0168-3659(95)00076-3.

[34] X. Fu, Q. Ping, Y. Gao, Effects of formulation factors on encapsulation efficiency and release behaviour in vitro of huperzine A-PLGA microspheres., J. Microencapsul. 22 (2005) 705-714. https://doi.org/10.1080/02652040500162196.

[35] X. Luan, M. Skupin, J. Siepmann, R. Bodmeier, Key parameters affecting the initial release (burst) and encapsulation efficiency of peptide-containing poly(lactide-co-glycolide) microparticles., Int. J. Pharm. 324 (2006) 168-175. https://doi.org/10.1016/j.ijpharm.2006.06.004.

[36] H. Park, D.H. Ha, E.S. Ha, J.S. Kim, M.S. Kim, S.J. Hwang, Effect of stabilizers on encapsulation efficiency and release behavior of exenatide-loaded PLGA microsphere prepared by the W/O/W solvent evaporation method, Pharmaceutics. 11 (2019). https://doi.org/10.3390/pharmaceutics11120627.

[37] J. Siepmann, N. Faisant, J. Akiki, J. Richard, J.P. Benoit, Effect of the size of biodegradable microparticles on drug release: experiment and theory., J. Control. Release. 96 (2004) 123-134. https://doi.org/10.1016/j.jconrel.2004.01.011. 
[38] D. Klose, F. Siepmann, K. Elkharraz, S. Krenzlin, How porosity and size affect the drug release mechanisms from PLGA-based microparticles, Int. J. Pharm. 314 (2006) 198-206. https://doi.org/10.1016/J.IJPHARM.2005.07.031.

[39] Y. Boukari, D.J. Scurr, O. Qutachi, A.P. Morris, S.W. Doughty, C. V Rahman, N. Billa, Physicomechanical properties of sintered scaffolds formed from porous and protein-loaded poly(DL-lactic-co-glycolic acid) microspheres for potential use in bone tissue engineering., J. Biomater. Sci. Polym. Ed. 26 (2015) 796-811. https://doi.org/10.1080/09205063.2015.1058696.

[40] E. D’Aurizio, C.F. van Nostrum, M.J. van Steenbergen, P. Sozio, F. Siepmann, J. Siepmann, W.E. Hennink, A. Di Stefano, Preparation and characterization of poly(lacticco-glycolic acid) microspheres loaded with a labile antiparkinson prodrug., Int. J. Pharm. 409 (2011) 289-296. https://doi.org/10.1016/j.ijpharm.2011.02.036.

[41] C.K. Sackett, B. Narasimhan, Mathematical modeling of polymer erosion: Consequences for drug delivery, Int. J. Pharm. 418 (2011) 104-114. https://doi.org/10.1016/J.IJPHARM.2010.11.048.

[42] A.N. Ford Versypt, D.W. Pack, R.D. Braatz, Mathematical modeling of drug delivery from autocatalytically degradable PLGA microspheres--a review., J. Control. Release. 165 (2013) 29-37. https://doi.org/10.1016/j.jconrel.2012.10.015.

[43] D. Klose, F. Siepmann, K. Elkharraz, J. Siepmann, PLGA-based drug delivery systems: importance of the type of drug and device geometry., Int. J. Pharm. 354 (2008) 95-103. https://doi.org/10.1016/j.ijpharm.2007.10.030.

[44] A.N. Ford Versypt, P.D. Arendt, D.W. Pack, R.D. Braatz, Derivation of an Analytical Solution to a Reaction-Diffusion Model for Autocatalytic Degradation and Erosion in Polymer Microspheres., PLoS One. 10 (2015) e0135506. https://doi.org/10.1371/journal.pone.0135506.

[45] C. Berkland, E. Pollauf, C. Raman, R. Silverman, K. "Kevin" Kim, D.W. Pack, Macromolecule release from monodisperse PLG microspheres: control of release rates and investigation of release mechanism., J. Pharm. Sci. 96 (2007) 1176-1191. https://doi.org/10.1002/jps.20948.

[46] C.-H. Zheng, J.-Q. Gao, W.-Q. Liang, H.-Y. Yu, Y.-L. Zhang, Effects of additives and processing parameters on the initial burst release of protein from poly(lactic-co-glycolic acid) microspheres., PDA J. Pharm. Sci. Technol. 60 (2006) 54-59.

[47] X. Huang, N. Li, D. Wang, Y. Luo, Z. Wu, Z. Guo, Q. Jin, Z. Liu, Y. Huang, Y. Zhang, C. $\mathrm{Wu}$, Quantitative three-dimensional analysis of poly (lactic-co-glycolic acid) microsphere using hard X-ray nano-tomography revealed correlation between structural parameters and drug burst release., J. Pharm. Biomed. Anal. 112 (2015) 43-49. https://doi.org/10.1016/j.jpba.2015.04.017.

[48] T. Hickey, D. Kreutzer, D.J. Burgess, F. Moussy, Dexamethasone/PLGA microspheres for continuous delivery of an anti-inflammatory drug for implantable medical devices., Biomaterials. 23 (2002) 1649-1656. https://doi.org/10.1016/s0142-9612(01)00291-5.

[49] S. Duvvuri, K.G. Janoria, D. Pal, A.K. Mitra, Controlled delivery of ganciclovir to the retina with drug-loaded Poly(d,L-lactide-co-glycolide) (PLGA) microspheres dispersed in 
PLGA-PEG-PLGA Gel: a novel intravitreal delivery system for the treatment of cytomegalovirus retinitis., J. Ocul. Pharmacol. Ther. 23 (2007) 264-274. https://doi.org/10.1089/jop.2006.132. 